\title{
UPAYA MENINGKATKAN HASIL BELAJAR SISWA DENGAN \\ MENGGUNAKAN MODEL PEMBELAJARAN INSIDE OUTSIDE \\ CIRCLE PADA TEMA TEMPAT TINGGALKU DI KELAS IV SD NEGERI 068003 TAHUN PEMBELAJARAN 2018/2019
}

\author{
SARI NAULI SITUMORANG \\ (PGSD FKIP UNIVERSITAS KATOLIK SANTO THOMAS)
}

\begin{abstract}
This type of research is class action research (PTK). This research aims to improve students ' learning outcomes by using the Inside Outside Circle theme of my residence in the sub I'm proud of my place to stay class IV Elementary school 068003 Medan Year learning 2018/2019. The subject in this study was a grade IV student of SD Negeri 068003 Medan which numbered 22 people consisting of 12 male students and 10 female students. The study consists of two cycles namely cycle I and cycle II. Each cycle consists of a one-time meeting. To obtain data during the study post-test used twice in two cycles to determine the increase in student learning outcomes and the teacher activity observation sheet to determine the effectiveness of models used by teachers and sheets Students to learn the extent to which students can apply a learning model that is conceived in the learning process.

The results showed that by using the Inside Outside Circle model in Cycle 1 , the average student learning results were $64.54 \%$ or about $54.55 \%$ of students who completed the results of 12 students. The results on this I cycle have not yet reached the expected outcome level. It is done cycle II and the average value of student learning outcomes is $81.27 \%$ with a percentage of $90.90 \%$ of students who have completed a total value of 20 students. Thus there is an increase in student learning outcomes of $90.90 \%$. Based on the results of the data obtained, it can be concluded that the use of the Inside Outside Circle model can improve the learning outcomes of grade IV students of elementary School 068003 Medan year of learning 2018/2019.
\end{abstract}

Keywords: Student learning results, a theme where I am a Model Inside Outside Circle

\section{PENDAHULUAN}

\section{Latar Belakang Masalah}

Pendidikan adalah salah satu sarana penting untuk meningkatkan kualitas sumber daya manusia (SDM) dalam menjamin keberlangsungan pembangunan suatu bangsa. Peningkatan kualitas SDM jauh lebih mendesak untuk segera direalisasikan terutama dalam menghadapi era persaingan global. Oleh karena itu, peningkatan kualitas SDM sejak dini merupakan hal penting yang harus dipikirkan secara sungguh-sungguh. Menurut Undang-Undang No. 20 Tahun 
2003 bahwa pendidikan adalah sebuah usaha sadar yang terencana untuk mewujudkan suasana belajar dan proses pembelajaran agar peserta didik secara aktif mengembangkan potensi yang ada dalam dirinya untuk memiliki kekuatan spiritual keagamaaan, pengendalian diri, kepribadian, kecerdasan, akhlak mulia, serta keterampilan yang diperlukan dirinya, masyarakat, bangsa, dan negara. Dalam pengertian ini, bahwa pada proses pembelajaran siswa diharapkan aktif dalam melakukan pembelajran yang diajarkan oleh guru dan menerima pembelajaran dengan ranah kognitif, aktif dan psikomotorik yang ada di dalam diri siswa. Pendidikan dapat melatih kemampuan anak dengan tujuan meningkatkan kecerdasaan siswa.

Untuk meningkatkan mutu pendidikan maka pemerintah memperbaharui kurikulum pendidikan sesuai dengan perkembangan zaman, yaitu dengan diberlakukannya Kurikulum 2013. Pendidikan akan berjalan dengan adanya peran siswa, guru, tenaga kependidikan, orang tua, dan aparatur institusi pendidikan dalam ekosistem pendidikan yang kuat. Dalam pendidikan dilaksanakan pembelajaran yang meningkatkan karakter siswa dengan mengembangkan sikap spiritual, sikap sosial, pengetahuan dan keterampilan. Menurut Winecoff (Dimyati dan. Mudjiono, 2013: 266) "Kurikulum didefinisikan sebagai satu rencana yang dikembangkan untuk mendukung proses mengajar/belajar di dalam arahan dan bimbingan sekolah dan mencapai tujuan pembelajaran".

Berdasarkan wawancara peneliti dengan guru kelas IV SD Negeri 068003 bahwa dalam proses pembelajaran guru masih menggunakan metode ceramah sehingga siswa bosan, ngantuk, dan kurang aktif pada saat proses pembelajaran. Dalam melaksanakan proses pembelajaran siswa hanya pasif mendengar perintah guru dan hanya bertugas mencatat materi yang disampaikan oleh guru. Siswa tidak antusias dengan pembelajaran yang sedang berlangsung bahkan banyak diantaranya yang sibuk bermain dan mengobrol dengan temannya sendiri sehingga tidak mendengarkan penjelasan guru. Ada yang masih berlarian didalam kelas dan ada yang sengaja pergi ke luar kelas untuk tidak mengikuti pelajaran, sehingga pembelajaran cenderung tidak memberikan kemandirian kepada siswa agar bisa menemukan sendiri pengetahuannya. Hal tersebut juga 
disebabkan karena pembelajaran yang berlangsung kurang menggunakan metode yang menarik dan hanya terpaut pada apa yang disediakan di buku kemudian guru menyampaikannya didepan kelas.

Oleh karena itu, guru masih kurang mampu memanfaatkan media dalam pembelajaran belum mampu sebagai pengantar menuju proses pembelajaran yang ideal. Variasi model mengajar yang kurang dilaksanakan berakibat siswa kurang aktif dan kurang tertarik dengan adanya pelajaran sehingga siswa menjadi bosan dan hasil belajarnya kurang maksimal. Kondisi ini tentu sangat berdampak kurang baik pada hasil belajar siswa.

Demikian juga dapat dilihat pada tabel di bawah ini bahwa hasil belajar siswa pada tema Tempat Tinggalku di kelas IV Kayu Manis Perumnas Simalingkar Kec. Medan Tuntungan Tahun Pembelajaran 2018/2019 masih dibawah KKM.

Tabel Nilai Harian Siswa Tema Tempat Tinggalku Siswa Kelas IV SD Negeri 068003 Medan

\begin{tabular}{|c|c|c|c|c|}
\hline $\begin{array}{c}\text { Mata } \\
\text { Pembelajaran }\end{array}$ & KKM & $\begin{array}{c}\text { Tidak } \\
\text { Memenuhi } \\
\text { KKM }\end{array}$ & $\begin{array}{c}\text { Memenuhi } \\
\text { KKM }\end{array}$ & Keterangan \\
\hline IPA & 65 & $\begin{array}{c}19 \text { Orang } \\
(65,51) \%\end{array}$ & $\begin{array}{c}10 \text { Orang } \\
(34,48) \%\end{array}$ & Tidak Tuntas \\
\hline IPS & 65 & 16 Orang & 13 Orang & Tidak Tuntas \\
& & $(55,17) \%$ & $(44,82) \%$ & \\
\hline PPKn & 65 & 16 Orang & 13 Orang & Tidak Tuntas \\
& & $(55,17) \%$ & $(44,82) \%$ & \\
\hline SBdP & 65 & 16 Orang & 13 Orang & Tidak Tuntas \\
& & $(55,17) \%$ & $(44,82) \%$ & \\
\hline
\end{tabular}

Berdasarkan tabel di atas, dapat dilihat bahwa hasil yang diperoleh siswa yang masih belum memenuhi Kriteria Ketuntasan Minimal (KKM) yaitu di bawah angka 65. Pada mata pelajaran IPA Dari 19 siswa yang tuntas hasil belajarnya hanya 10 orang sekitar $34,48 \%$ yang nilainya di atas 65 , dan siswa yang tidak 
tuntas hasil belajar adalah 19 orang siswa sekitar 63,3\% di bawah KKM 65, pada mata pelajaran IPS yang tuntas hasil belajarnya hanya 13 orang sekitar 44,82\% yang di atas 65 , dan siswa yang tidak tuntas hasil belajar adalah 16 orang sekitar $55,17 \%$ di bawah KKM 65, pada mata pelajara SBdP IPS yang tuntas hasil belajarnya hanya 13 orang sekitar $44,82 \%$ yang di atas 65 , dan siswa yang tidak tuntas hasil belajar adalah 16 orang sekitar 55,17\% di bawah KKM 65, pada mata pelajaran PPKn yang tuntas hasil belajarnya hanya 13 orang sekitar 44,82\% yang di atas 65, dan siswa yang tidak tuntas hasil belajar adalah 16 orang sekitar $55,17 \%$ di bawah KKM 65. Oleh karena itu, peneliti mencari solusi untuk memecahkan masalah yang dapat digunakan dalam menigkatkan hasil belajar pada tema Tempat Tinggalku yaitu dengan menggunakan model pembelajaran Inside Outside Circle.

Penelitian ini sejalan dengan hasil penelitian yang dilakukan oleh Hasil penelitian yang dilakukan oleh Noor Fitria Ramadhani 2015 Penerapan strategi Inside Outside Circle dalam upaya meningkatkan penguasaan konsep dan hasil belajar pada pembelajaran IPA kelas V SDN Tlogoharum 02 wedarijaksa pati tahun ajaran 2014/2015. Penelitian ini merupakan penelitian tindakan kelas yang dilaksankan dalam dua siklus dengan tujuan meningkatan kemampuan penguasan konsep dan hasil belajar siswa melalui strategi inside outside circle masingmasing siklus terdiri dua pertemuan, tiap pertemuan melalui 2 tahap yaitu perencanaan, tindakan, observasi, dan refleksi. Subjek penerima tindakan adalah siswa kelas V SDN Tlogoharum 02 yang berjumlah 37 siswa, subjek pelaku tindakan yaitu peneliti dan guru. Teknik pengumpulan data dengan menggunakan metode wawancara, observasi, dokumentasi, dan tes. Variabel yang menjadi sasaran peneliti adalah kemampuan penguasan konsep dan hasil belajar siswa. Teknik analisis data yang digunakan adalah model analisis interaktif yang memiliki tiga komponen yaitu reduksi data, paparan data dan penyimpulan. Hasil penelitian menunjukan adanya peningkatan penguasan konsep dan hasil belajar siswa setelah diadakan tindakan kelas dengan menggunakan metode inside outside circle hal ini dapat dilihat dari penguasan konsep siswa kondisi awal sebesar $48,65 \%$ mengalami peningkatan pada siklus I sebesar $62,16 \%$ dan siklus II 
sebesar $81,08 \%$. Hasil belajar pada kondisi awal sebesar 54,05\% juga mengalami peningkatan pada siklus I sebesar 70,27\% dan pada siklus II sebesar 86,48\%. Dengan demikian dapat diketahui bahwa pembelajaran IPA menggunakan strategi inside outside circle dapat meningkatkan penguasan konsep dan hasil belajar siswa kelas V SDN Tlogoharum 02 tahun ajaran 2014/2015.

Menurut Spencer Kagan (dalam Huda 2013:246) menyatakan bahwa "Model Pembelajaran Inside Outside Circle merupakan sistem pembelajaran kelompok dengan tujuan agar siswa dapat berbagai informasi dengan singkat dan teratur. Model ini juga melatih siswa untuk menolah informasi dan meningkatkan keterampilan berkomunikasi dengan menggunakan model pembelajaran Inside Outside Circle".

Berdasarkan latar belakang tersebut, peneliti tertarik untuk melakukan penelitian tindakan kelas dengan judul "Upaya Meningkatkan Hasil Belajar Siswa Dengan Menggunakan Model Pembelajaran Inside Outside Circle Pada Tema Tempat Tinggalku di Kelas IV SD Negeri 068003 Jl. Kayu Manis Perumnas Simalingkar Kec. Medan Tuntungan Tahun Pembelajaran 2018/2019"

\section{Identifikasi Masalah}

Berdasarkan latar belakang masalah yang telah diuraikan di atas, maka dapat ditentukan identikikasi masalah yang ada di SD Negeri 068003 adalah sebagai berikut:

1. Model pembelajaran yang digunakan guru masih bersifat berpusat pada guru.

2. Siswa kurang aktif dalam proses pembelajaran

3. Rendahnya hasil belajar siswa

\section{Pembatasan Masalah}

Berdasarkan identifikasi masalah yang di uraikan di atas maka batasan masalahnya adalah "Upaya Meningkatkan Hasil Belajar Siswa Dengan Menggunakan Model Inside Outside Circle pada Tema Tempat Tinggalku dengan subtema Bangga Terhadap Daerah Tempat Tinggalku di kelas IV SD Negeri 068003 Medan Tuntungan Tahun Pembelajaran 2018/2019”. 


\section{Perumusan Masalah}

Berdasarkan batasan masalah di atas, maka rumusan peneliti ini adalah:

1. Bagaimanakah pelaksanaan pembelajaran dengan menggunakan model pembelajaran Inside Outside Circle pada Tema Tempat Tinggalku dengan subtema Bangga Terhadap Daerah Tempat Tinggalku dapat meningkatkan hasil belajar siswa kelas IV SD Negeri 068003 Medan Tuntungan Tahun Pembelajaran 2018/2019?

2. Apakah dengan menggunakan model pembelajaran Inside Outside Circle dalam pembelajaran pada Tema Tempat Tinggalku dengan subtema Bangga Terhadap Daerah Tempat Tinggalku dapat meningkatkan hasil belajar siswa kelas IV SD Negeri 068003 Medan Tuntungan Tahun Pembelajaran $2018 / 2019 ?$

\section{Tujuan Penelitian}

Tujuan penelitian ini adalah :

1. Untuk mengetahui pelaksanaan pembelajaran dengan menggunakan model pembelajaran Inside Outside Circle pada Tema Tempat Tinggalku dengan subtema Bangga Terhadap Daerah Tempat Tinggalku dapat meningkatkan hasil belajar siswa kelas IV SD Negeri 068003 Medan Tuntungan Tahun Pembelajaran 2018/2019

2. Untuk mengetahui peningkatan hasil belajar siswa dalam pembelajaran Tema Tempat Tinggalku dengan subtema Bangga Terhadap Daerah Tempat Tinggalku menggunakan model pembelajaran Inside Outside Circle pada siswa kelas IV SD Negeri 068003 Medan Tuntungan Tahun Pembelajaran $2018 / 2019$

\section{Manfaat Penelitian}

1. Manfaat Teoritis

Manfaat teoritis artinya hasil penelitian bermanfaat untuk mengembangkan tema tempat tinggalku dari hasil penelitian dan pembahasan yang telah dilakukan serta menambah referensi di bidang pendidikan dengan meningkatkan hasil belajar siswa kelas IV di Sekolah Dasar.

2. Manfaat Praktis 
Manfaat praktis artinya manfaat yang secara langsung dalam pembelajaran dari hasil Penelitian Tindakan Kelas ini adalah

\section{Bagi Siswa}

Dengan menggunakan model pembelajaran Inside Outside Circle dapat meningkatkan keaktifan bagi siswa dalam belajar tempat tinggalku dapat meningkatkan hasil belajar siswa, serta mempermudah guru mencapai tujuan pembelajaran

2. Bagi guru

Sebagai bahan masukan kepada guru untuk memilih model pembelajaran Inside Outside Circle, mempermudah guru untuk mencapai tujuan pembelajaran dan juga memberikan pengalaman yang baru dalam hal kegiatan belajar mengajar.

\section{Bagi sekolah}

Sebagai peningkatan mutu para pendidik dan juga peserta didik yang dijadikan tolak ukur untuk meningkatkan hasil belajar siswa.

\section{Bagi peneliti}

Sebagai usaha untuk meningkatkan kemapuan sebagai calon pendidik yang akan datang dan mengembangkan kreativitas agar mampu memberikan pemahaman yang lebih baik untuk peserta didik.

\section{METODOLOGI PENELITIAN}

\section{Pendekatan dan Metode Penelitian}

Pendekatan yang digunakan dalam penelitian ini adalah pendekatan campuran. Pendekatan yang dimaksud campuran adalah merupakan gabungan dari dua metode yaitu metode kualitatif dan metode kuantitatif. Pengunaan dua metode ini dipandang lebih memberikan pemahaman yang lebih lengkap tentang permasalahan penelitian dari pada salah satu penggunaan metode tersebut. Metode yang digunakan adalah penelitian tindakan kelas. Penelitian tindakan kelas adalah penelitian praktis yang dilakukan oleh guru untuk memperbaiki proses belajar mengajar baik dari alat, media, sumber, metode, strategi, maupun model yang digunakan guru.

\section{Tempat dan waktu Penelitian}




\section{Tempat Penelitian}

Penelitian ini dilakukan di sekolah SD Negeri 068003 JL. Kayu Manis Perumnas Simalingkar Kec.Medan Tuntungan. Alasan peneliti memilih lokasi penelitian ini didasarkan atas pertimbangan sebagai berikut:

1. SD Negeri 068003 Medan belum pernah diadakan penelitian dengan judul yang sama dengan judul peneliti Upaya Meningkatkan Hasil Belajar Siswa DenganMenggunakan Model Pembelajaran Inside Outside Circle Pada Tema Tempat Tinggalku Dengan Subtema Bangga Terhadap Daerah Tempat Tinggalku di Kelas IV SD Negeri 068003 Jl. Kayu Manis Perumnas Simalingkar Kec. Medan Tuntungan Tahun Pembelajaran 2018/2019.

2. Pelaksanaan pembelajaran di SD Negeri 068003 Medan tersebut masih belum optimal dan hasil belajar siswa belum optimal.

\section{Waktu Penelitian}

Penelitian ini dilakukan pada semester Genap tahun pembelajaran 2018/2019. Waktu pelaksanaan penelitian dilakukan pada bulan maret 2019

\section{Subjek Penelitian}

\section{Subjek Penelitian}

Peneliti melakukan penelitian adalah di kelas IV SD Negeri 068003 dengan jumlah siswa secara keseluruhan yaitu 22 orang siswa .Dari 22 orang siswa terdapat 12 orang siswa laki-laki dan 10 orang siswa perempuan.Alasan peneliti memilih kelas IV SD Negeri 068003 Medan sebagai subjek pene;litian didasarkan pada hasil observasi dan wawancara yang dilakukan dengan wali kelas. Berdasarkan hasil observasi dan wawancara dengan wali kelas, siswa kurang aktif pada saat proses pembelajaran sehingga hasil belajar yang diperoleh siswa kurang optimal.

\section{Objek Penelitian}

Objek penelitian ini adalah dengan menggunakan Model pembelajaran Inside Outside Circle pada Tema Tempat Tinggalku subtema bangga terhadap daerah tempat tinggalku dapat meningkatkan hasil belajar siswa.

\section{Jenis dan Sumber Data}

\section{Jenis Data}


Jenis data yang digunakan dalam PTK berupa data kuantitatif dan data kualitatif

1. Data kuantitatif yaitu suatu penelitian yang memberikan nilai berupa angka pada tes.

2. Data kualitatif yaitu suatu penelitian yang bersifat menggambarkan kenyataan atau fakta sesuai dengan data yang diperoleh, dengan tujuan untuk mendeskripsikan aktivitas guru dan siswa selama prsoses pembelajaran.

\section{Sumber Data}

Sumber data yang diperlukan berasal dari dua yaitu:

1. Informasi dan narasumber yaitu guru kelas IV dan siswa kelas IV SD Negeri 068003

2. Tempat dan peristiwa berlangsung aktivitas pembelajaran dengan tema Tempat Tinggalku pada subtema 3 Bangga Terhadap Daerah Tempat Tinggalku pembelajaran 1 dan 4

\section{Teknik dan Alat Pengumpulan Data}

\section{Observasi}

Observasi merupakan teknik mengumpulkan data dengan cara mengamati setiap kejadian yang sedang berlangsung. Observasi juga berhubungan dengan kegiatan guru dan siswa.

\section{Lembar Observasi Kegiatan Guru}

Lembar observasi pada aktivitas guru digunakan untuk melihat pelaksanaan pembelajaran yang diadakan guru di dalam kelas selama proses pembelajaran berlangsung dengan menggunakan model Inside Outside Circle. Dalam melakukan observasi di kegiatan guru dibantu oleh observer dengan tujuan untuk memperoleh data.

\section{Tes}

Tes merupakan himpunan pertanyaan yang harus dijawab, harus ditanggapi, atau tugas yang harus dilaksanakan oleh orang yang dites.Tes digunakan untuk mengukur sejauh mana seorang siswa telah menguasai pelajaran 
yang disampaikan terutama meliputi aspek pengetahuan dan keterampilan (Jihad dan Haris, 2013: 67).

Tes yang digunakan dalam penelitian ini adalah tes hasil belajar yang digunakan untuk mengukur pencapaian seseorang setelah dikerjakan. Bentuk tes yang digunakan dalam penelitian ini adalah tes pilihan berganda. Dalam tes pilihan berganda, siswa diminta untuk memberikan jawaban yang benar dari pertanyaan yang disusun dalam lembar evaluasi.

Dalam penelitian ini, tes yang diberikan sesuai dengan indikator yang hendak dicapai. Instrumen yang digunakan dalam penelitian ini adalah evaluasi hasil belajar secara kongnitif.

\section{Uji Validitas Data dan Instrumen}

\section{Uji Validitas}

Validitas soal digunakan untuk mengetahui reabilitas tidaknya soal digunakan untuk mengetahui realibilitas tidaknya soal yang diujikan sehinga soal yang dinyatakan valid layak diujikan. Validitas merupakan derajat ketetapan antara data yang terjadi pada objek penelitian dengan daya yang dapat dilaporkan oleh penelitian.

Agar instumen yang dibuat oleh peneliti dapat dikatakan valid maka dilakukan uji validitas. Validitas dalam penelitian ini dilakukan dengan diuji dan diperiksa validitasnya, sehingga data tersebut dapat dipertanggungjawabkan. Perhitungan uji validitas ini menggunakan bantuan Statistical packagefor the Sosial Science SPSS. Uji validitas pada penelitian ini menggunakan poduct moment dengan mengkorelasikan anatar skor yang didapat siswa pada suatu butir soal dengan skor total yang didapat.

Adapun cara yang digunakan untuk mengukur validitas instrument sebagai berikut:

$r_{x y}=\frac{\mathrm{N} \sum \mathrm{XY}-\left(\sum \mathrm{X}\right)\left(\sum \mathrm{Y}\right)}{\sqrt{\left\{\mathrm{N} \sum \mathrm{X}-\left(\sum \mathrm{X}\right)^{2}\right\}\left\{\mathrm{N} \mathrm{Y}^{2}-\left(\sum \mathrm{Y}\right)^{2}\right\}}}$ (Jihad dan Haris, 2013:

Keterangan:

$r_{x y}=$ Koefisien korelasi antara $\mathrm{X}$ dan $\mathrm{Y}$

$\mathrm{N}$ = Banyak nya peserta tes 
$\mathrm{X}=$ Nilai hasil uji coba

$\mathrm{Y}=$ rata-rata siswa

Interpretasi terhadap nilai koefisien korelasir $r_{x y}$ digunakan kriteria (Jihad, 2013 : 180) berikut ini:

$0,80<r_{x y} \leq 1,00 \quad$ : Sangat baik

$0,60<r_{x y} \leq 0,80$ : Tinggi

$0,40<r_{x y} \leq 0,60$ : Cukup

$0,20<r_{x y} \leq 0,40:$ Rendah

$\mathrm{r}_{\mathrm{xy}} \leq 0,20 \quad$ : Sangat Rendah

Instrumen soal pada peneliti ini dapat dikatakan valid jika $r_{x y}>r_{\text {tabel }}$ pada uji validitas ini adalah sebesar 0,423 dengan taraf signifikan 5\% dengan jumlah $\mathrm{N}$ dan diujikan kevalidnnya dengan menggunakan program SPSS.

\section{Uji Realiabilitas Instrument}

Reabilitas soal merupakan ukuran yang menyatakan tingkat keajengan atau kekonsistenan suatu soal tes. Bila suatu alat pengukur dipakai dua kali untuk mengukur gejala yang sama dan hasilo pengukuran diperoleh relatif koefisien, maka alat pengukur tersebut dikatakan reliabel. Untuk mengukur tingkat keajengan soal ini digunakan perhitungan Alpha Cronbach.

Rumus yang digunakan dinyatakan dengan:

$\mathrm{r}_{11}=\left(\frac{n}{n-1}\right)\left(\frac{S^{2}-\sum \mathrm{pq}}{S^{2}}\right) \ldots \ldots \ldots \ldots . . . \mathrm{p}=$ indeks/tingkat kesukaran (Arikunto, 2013: 115)

Sebelum menghitung reliabilitas tes, terlebih dahulu dicari varians total dengan menggunakan :

$\mathrm{S}^{2}=\left(\frac{\sum Y^{2}-\frac{\Sigma Y^{2}}{N}}{N}\right)$

Keterangan:

$\mathrm{r}_{11}=$ reliabilitas tes secara keseluruhan

$\mathrm{n} \quad$ = banyaknya butir soal

$\mathrm{p} \quad=$ proporsi subjek yang menjawab item dengan benar

$\mathrm{q}=$ proporsi subjek yang menjawab item dengan salah $(\mathrm{q}=1-\mathrm{p})$

$\sum \mathrm{pq} \quad=$ jumlah hasil perkalian antara $\mathrm{p}$ dan $\mathrm{q}$ 
$\mathrm{S} \quad=$ standar deviasi dari tes

$\mathrm{S}^{2} \quad=$ varians skor

$\sum \mathrm{Y} \quad=$ jumlah skor total

$\sum Y^{2}=$ jumlah kuadrat skor

$\mathrm{N} \quad=$ sampel

Koefisien reliabilitas yang dihasilkan data dapat diinterpretasikan dengan pedoman kriteria Jihad dan Haris (2013: 181) seperti tabel di bawah ini,

Makna koesien korelasi product moment

\begin{tabular}{|l|l|}
\hline \multicolumn{1}{|c|}{ Angka Korelasi } & \multicolumn{1}{c|}{ Makna } \\
\hline$r_{11} \leq 0,020$ & Sangat Rendah \\
\hline $0,20<r_{11} 0,40$ & Rendah \\
\hline $0,40<r_{11} 0,70$ & Sedang \\
\hline $0,70<\mathrm{r}_{11} \leq 0,90$ & Tinggi \\
\hline $0,90<\mathrm{r}_{11} \leq 1,00$ & Sangat Tinggi \\
\hline
\end{tabular}

Berikut ini adalah hasil perhitungan uji reabilitas soal dengan menggunakan SPSS 22 statistik pada tabel di bawah ini:

\section{Reliabilitiy Statiststics}

\begin{tabular}{|c|c|}
\hline Cronbach's Alpha & N of Items \\
\hline .797 & 50 \\
\hline
\end{tabular}

Hasil yang diperoleh daru uji reliabilitas item soal $r_{11}=0,797$. Jika hasil reliabilitas ini diinterprestasikan dengan koefisien korelasi di atas maka reliabilitas yang diperoleh pada item soal berada pada reliabilitas tinggi.

\section{TeknikAnalisis Data}

Setelah data dikumpulkan, maka langkah selanjutnya adalah analisis terhadap hasil-hasil yang telah diperoleh. Analisis data adalah proses mencari dan menyusun secara sistematis data yang diperoleh dari hasil observasi, tes, dan dokumentasi dengan cara mengorganisasikan data ke dalam kategori, menjabarkan ke dalam unit-unit, melakukan sintesa, menyusun ke dalam pola, 
memilih mana yang penting dan yang akan dipelajari dan membuat kesimpulan sehingga mudah dipahami oleh diri sendiri maupun orang lain (Sugiyono, 2017:335).

Analisis data dilakukan untuk mengetahui berhasil tidaknya penelitian tindakan kelas yang dilakukan. Untuk menganalisis data hasil pelaksanaan pembelajaran maka digunakan sebagai berikut :

\section{Pelaksanaan Pembelajaran}

1. Untuk menghitung data hasil pembelajaran aktivitas guru digunakan rumus sebagai berikut:

Nilai $=\frac{\text { Total skor }(\text { perolehan })}{\text { Jumlah skor keseluruhan }} \times \quad 100 \%$ Tampubolon $(2014$

Adapun kriteria yang digunakan untuk hasil pembelajaran aktivitas guru adalah sebagai berikut :

Tabel Kriteria Penilaian dalam pembelajaran

\begin{tabular}{|c|c|l|}
\hline No & Rentang Nilai & \multicolumn{1}{|c|}{ Kriteria } \\
\hline 1 & $81-100 \%$ & Sangat berkualitas \\
\hline 2 & $61-80 \%$ & Berkualitas \\
\hline 3 & $41-60 \%$ & Cukup \\
\hline 4 & $21-40 \%$ & Kurang berkualitas \\
\hline 5 & $0-20 \%$ & Sangat kurang berkualiatas \\
\hline
\end{tabular}

2. Untuk menghitung data hasil pembelajaran aktivitas siswa digunakan rumus sebagai berikut:

Nilai siswa : $\frac{\text { Skorperolehan }}{\text { skormaksimum }} \times 100$ (Jihad \& Haris, 2013: 130)

Adapun kriteria yang digunakan untuk hasil pembelajaran siswa adalah sebagai berikut :

\section{Kriteria ketuntasan siswa}




\begin{tabular}{|c|c|c|}
\hline No & Rentang Nilai & Kriteria \\
\hline 1 & $90-100$ & Sangat baik \\
\hline 2 & $70-89$ & Baik \\
\hline 3 & $50-69$ & Cukup \\
\hline 4 & $30-49$ & Kurang \\
\hline 5 & $10-29$ & Sangat Kurang \\
\hline
\end{tabular}

\section{Hasil Belajar}

\section{a. Ketuntasan BelajarIndividu}

Proses pembelajaran berhasil dikatakan berhasil jika siswa memperoleh hasil belajar sesuai dengan KKM yang ditentukan oleh sekolah yaitu 65. Untuk menghitung ketuntasan belajar siswa dapat dihutung dengan menggunakan rumus sebagai berikut:

$\mathrm{KB}: \frac{T}{T t} x 100 \%$ (Trianto, 2009: 241)

Keterangan:

$$
\begin{array}{ll}
\mathrm{KB} & =\text { ketuntasan belajar } \\
\mathrm{T} & =\text { jumlah skor yang diperoleh } \\
\mathrm{Tt} & =\text { jumlah skor total }
\end{array}
$$

\section{b. Ketuntasan Hasil Belajar Siswa (Klasikal)}

Dalam proses pembelajaran, suatu kelas dikatakan tuntas hasil belajarnya jika dalam kelas terdapat $75 \%$ siswa yang telah tuntas sesuai dengan nilai KKM yang telah ditetapkan yaitu 65. Untuk mengetahui ketuntasan hasil belajar siswa secara klasikal dapat dilakukan dengan menggunakan rumus sebagai berikut :

$\mathrm{P}: \frac{\text { Ssiswayangtuntasbelajar }}{\sum \text { siswa }} \times 100 \%$

(Aqib dkk, 2013:

\section{Tabel Kriteria Tingkat Keberhasilan Belajar Siswa Dalam \%}




\begin{tabular}{|c|c|}
\hline Tingkat Keberhasilan & Arti \\
\hline$>80 \%$ & Sangat Tinggi \\
\hline $60-76 \%$ & Tinggi \\
\hline $40-59 \%$ & Sedang \\
\hline $20-39 \%$ & Rendah \\
\hline$<20 \%$ & Sangat Rendah \\
\hline
\end{tabular}

\section{c. Rata-rata Hasil BelajarSiswa}

Peneliti menjumlahkan nilai yang diperoleh siswa kemudian dibagikan dengan jumlah siswa sehingga diperoleh nilai rata-rata. Untuk menghitung nilai rata-rata dapat diperoleh dengan menggunakan rumus sebagai berikut:

$\mathrm{x}: \frac{\sum x}{\sum N}$ (Aqib dkk, 2013: 40)

Keterangan:

$\mathrm{x}=$ nilai rata-rata

$\sum \mathrm{x} \quad=$ jumlah semua nilai siswa

$\sum \mathrm{N} \quad=$ jumlah siswa

\section{Indikator Kinerja Penelitian}

Menurut Tampubolon (2014: 35) urutan indikator secara logika ilmiah disusun kembali menjadi :

1. Indikator keberhasilan kualitas proses pembelajaran minimal "baik" (indicatoriniuntuktujuanumumdaritujuanpenelitian).

2. Indikatorkeberhasilanhasilbelajarklasikal minimal $75 \%$ darijumlahsiswa mencapai $\mathrm{KKM}=65$.

\section{Prosedur Penelitian}

Berdasarkan jenis penelitian yang digunakan yaitu Penelitian Tindakan Kelas (PTK) maka desain penelitian yang digunakan memilikitahapan-tahapan. Secara garis besar ada empat tahapan yang dilalui dalam melaksanakan penelitian tindakan kelas yaitu : 1) perencanaan, 2) pelaksanaan, 3) pengamatan, 4) refleksi.

Penelitian tindakan kelas ini memiliki empat tahap pelaksanaan tindakan yang berupa siklus-siklusyang dimulai dari perencanaan, tindakan, observasi 
(pengamatan) dan refleksi.Prosedur penelitian ini dilakukan dalam 2 siklus. Adapun tahapannya sebagai berikut

\section{Prasiklus}

Prasiklus ini dilakukan untuk mengetahui hasil belajar siswa sebelum masuk dalam siklus I yang menerapkan model pembelajaran Inside Outside Circle hasil belajar siswa diketahui dari pemberian soal yang akan dikerjakan siswa Tema Tempat Tinggalku Subtema Aku Bangga Dengan Tempat Tinggalku pada Pembelajaran 1 dan Pembelajaran 4

\section{Siklus I}

Siklus ini dilaksanakan untuk memperbaiki proses pembelajaran agar hasil belajar siswa meningkat. Berdasarkan rancangan perangkat pembelajaran dapat disusun sebelumnya perencanaan tindakan untuk siklus pertama sebagai berikut:

\section{1) PerencanaanTindakan}

a. Melakukan kerjasama dengan guru untuk membuat cara meningkatkan hasil belajar siswa.

b. Menyusun materi proses pembelajaran

c. Menyusun Rencana Pelaksanaan Pembelajaran (RPP) yang akan digunakan

d. Menentukan dan mempersiapkan media yang akan digunakan

e. Menyusun lembar observasi untuk guru dan siswa

f. Mempersiap bahan ajar yang digunakan pada saat proses pembelajaran

g. Menyusun soal tes yang akan digunakan pada setiap siklus untuk mengetahui peningkatan hasil belajar siswa.

\section{2) PelaksanaanTindakan}

Adapun teknis pelaksanaan kegiatan tindakan kelas pada siklus I adalah sebagai berikut:

- Gurumemberikan salam dan mengajak semua siswa berdo'a menurut agama dan keyakinan masing-masing.

- Gurumengecek kesiapan diri dengan mengisi lembar kehadiran dan memeriksa kerapihan pakaian, posisi dan tempat duduk disesuaikan dengan kegiatan pembelajaran. 
- Guru melakukan apersepsi

- Guru menyampaikan tujuan pembelajaran

- Guru memberikan pretes pada siswa

- Guru membentuk kelompok yang terdiri dari 5-6 orang

- Separuh kelas berdiri membentuk lingkaran kecil, mereka berdiri melingkar menghadap keluar.

- Separuh kelas lagi membentuk lingkaran besar, mereka berdiri menghadap ke dalam.

- Kemudian siswa berada di lingkaran kecil diam di tempat, sementara siswa yang berada di lingkaran besar bergeser satu atau dua langkah searah jarum jam.

- Setiap pasangan peserta didik dari lingkaran kecil dan besar saling berbagi informasi.

- Sekarang giliran siswa berada di lingkaran besar yang membagi informasi. Demikian seterusnya, sampai seluruh siswa selesai berbagi informasi.

- Sekarang, giliran peserta didik yang berada di lingkaran besar yang membagikan informasi, demikian seterusnya.

- Setiap kelompok berputar seperti prosedur lingkaran individu yang dijelaskan di atas sambil berbagi informasi

- Guru menjelaskan materi pembelajaran berdasarkan soal yang telah dikerjakan oleh siswa

- Guru memberikan soal pos tes

- Bersama-sama siswa membuat kesimpulan / rangkuman hasil belajar selama sehari

- Bertanya jawab tentang materi yang telah dipelajari (untuk mengetahui hasil ketercapaian materi).

- Mengajak semua siswa berdo'a menurut agama dan keyakinan masingmasing (untuk mengakhiri kegiatan pembelajaran)

- Guru memberikan salam dan meninggalkan kelas.

\section{3) Observasi}


Observasi dilakukan agar peneliti dapat melihat secara langsung objek yang akan diteliti untuk memperoleh data yang akurat. Observasi dilakukan di dalam kelas pada saat proses pembelajaran. Kegiatan observasi ini dilaksanakan untuk mengamati proses pembelajaran dan aktivitas guru dalam pelaksanaan proses pembelajaran untuk mengetahui kesesuaian tindakan dengan rencana yang telah disusun dan untuk mengetahui mana pelaksanaan tindakan yang akan dilakukan dapat mengalami perubahan dalam meningkatkan hasil belajar siswa.

\section{4) Refleksi}

Tahap ini dilaksanakan untuk mengkaji pembelajaran yang dilakukan dan melihat kesesuaian yang dicapai sesuai dengan yang diharapkan.Apabila ditemukan kekurangan dalam menerapkan pendekatan kontekstual maka tahap kegiatan terus berulang dan menentukan langkah dan perbaikan selanjutnya pada siklus II, sehingga pada siklus selanjutnya dapat mengatasi permasalahan yang terjadi.

\section{Siklus II}

Penelitian siklus II dilakukan jika hasil tindakan pada siklus yang sebelumnya tidak berhasil mencapai pemecahan permasalahan. Hasil refleksi pada siklus I dianalisa dan dilihat aspek-aspek mana yang perlu diperbaiki maka dilaksanakan siklus yang kedua dengan tahapan-tahapan sebagai berikut:

\section{Perencanaan}

Sebelum memulai pembelajaran, peneliti terlebih dahulu membahas proses pembelajaran dan hasil belajar yang telah dilaksanakan siklus I. Selanjutnya prosedur pelaksanaan siklus II disusun berdasarkan hasil refleksi dan analisis pada siklus sebelumnya.

\section{PelaksanaanTindakan}

Dalam tahap pelaksanaan tindakan kegiatan yang dilaksanakan adalah melakukan proses pembelajaran sesuai dengan rencana yang telah disusun dan sesuai dengan hasil refleksi dan analisis pada siklus I.

\section{Observasi}

Kegiatan ini dilaksanakan untuk mengamati proses pembelajaran secara langsung baik aktivitas guru saat mengajar dan aktivitas sisswa saat belajar. 
Tahapan ini dilakukan sesuai dengan siklus I. Kegiatan ini dilakukan untuk mengatasi proses pembelajaran yang terjadi di dalam kelas.

\section{Refleksi}

Kegiatan ini dilaksanakan pada akhir pertemuan. Pada tahap ini mengemukakan kembali jika terdapat kekurangan dalam pelaksanan tindakan yang terjadi di kelas, jika pada siklus ini belum mengalami peningkatan maka dilaksanakan siklus selanjutnya.Jika hasil yang diperoleh sudah memenuhi indikator keberhasilan yaitu $75 \%$ maka siklus berikutnya tidak perlu dilakukan lagi.

\section{HASIL PENELITIAN DAN PEMBAHASAN}

\section{Pembahasan Hasil Temuan}

Pada bahasan ini akan diuraikan hasil temuan dalam penelitian diperoleh melalui hasil pengamatan dan refleksi pada setiap siklusnya. Pada saat pelaksanaan pembelajaran tempat tinggalku dengan model pembelajaran inside outside circle pada siswa IV SD Negeri 068003 Medan Tuntungan dalam materi tempat tinggalku diperoleh temuan-temuan berdasarkan hasil observasi yang dilaksanakan selama proses pembelajaran.

\section{Hasil Belajar Siswa}

Pelaksanaan tindakan ini peneliti merancang dalam pembelajaran tempat tinggalku. Sebelum masuk pada siklus I peneliti melakukan prates untuk mengetahui sejauh mana pengetahuan dan kemampuan siswa dalam memahami materi tempat tinggalku. Dari hasil analisis pada prates dapat dinyatkan bahawa kemampuan siswa masih dibawah 75\%dengan rata-rata 41,44 sehingga mempengaruhi hasil belajar yang maksimal. Untuk mengatasi hal ini guru menggunakan model pembelajaran inside outside circle, dimana proses pembelajaran berdasarkan mencari informasi pada saat yang bersamaan dengan pasangan yang berbeda dengan singkat dan teratur.

Pada siklus I diperoleh tingkat ketuntasan belajar siswa dengan rata-rata 64,54. Melihat hasil ketuntasan belajar siswa pada siklus I siswa juga belum memahami materi tempat tinggalku.Peneliti tindakan ini belum mencapai tingkat 
keberhasilan dalam meningkatkan hasil belajar siswa hanya pada siklus I. Oleh karena itu, dari data yang diketahui pada siklus I menjadi panduan untuk memperbaiki hasil belajar siswa dengan merancang pelaksanaan pembelajaran yang lebih menyenangkan mungkin untuk mencapai hasil belajar yang maksimal.Pada siklus II, peneliti lebih focus dalam pemberiamn materi tempat tinggalku untuk merancang kembali model pembelajaran inside outside circle yang dapat membuat siswa menjadi aktif, menyenangkan, semangat belajar sehingga mendapat ketuntasan belajar yang maksimal. Setelah dilakukan evaluasi di akhir pertemuan diperoleh peningkatan hasil belajar siswa dengan nilai rata-rata 81,27 .

Dengan demikian dapat disimpulkan bahwa terjadi peningkatan hasil belajar siswa yang dilihat dari ketuntasan belajar siswa dimulai dari prates hingga ke siklus II atau dapat dikatakan melalui model pembelajaran inside outside circle dapat meningkatkan hasil belajar siswa terhadap materi temapat tinggalku di kelas IV SD Negeri 068003 Medan Tuntungan Tahun Pembelajaran 2018/2019.

\section{Hasil Pengamatan}

Berdasarkan data hasil pengamatan yang dilakukan pada aktivitas guru dan aktivitas siswa pada siklus I dan siklus II. Berikut penjabaran pengamatan sebagai berikut:

\section{Hasil Pengamatan Aktivitas Guru}

Pengamatan aktivitas guru dilakukan untuk mengukur kemampuan guru dalam melaksanakan pembelajaran dan kesesuian tindakan dengan rencana. Dari kegiatan aktivitas guru yang dinilai sebanyak 10 indikator setiap siklusnya dan observer mengamati setiap indikator dengan menyesuaikan kegiatan guru selama proses pemeblajaran berlangsung. Pada siklsu I dan siklus II ada peningkatan kegiatan guru selama proses pemebajaran berlangsung selama siklus diterapkan di dalam kelas. Siklus I pengamatan guru hanya $64 \%$ dan pada siklus II terjadi peningkatan sebesar $88 \%$. Hal ini menunjukkan bahwa sudah ada perubahan yang terjadi pada aktivitas guru di dalam kelas hingga hasil pengamatan aktivitas guru mengalami peningkatan dari kategori sangat berkualitas. 


\section{Hasil Pengamatan Aktivitas Siswa}

Pengamatan aktivitas siswa dilakukan untuk mengetahui aktivitas siswa dalam proses pembelajaran tempat tinggalku. Dari kegiatan aktivitas siswa yang dinilai sebanyak 10 indikator setiap siklusnya dan observer mengamati setiap indikator dengan menyesuaikan kegiatan siswa selama proses pemeblajaran berlangsung. Pada siklsu I dan siklus II ada peningkatan aktivitas siswa selama proses pembelajaran berlangsung selama siklus diterapkan di dalam kelas. Siklus I pengamatan siswa hanya sebesar $62 \%$ namun pada siklus II terjadi peningkatan $86 \%$.Hal ini menunjukkan bahwa sudah ada perubahan yang terjadi pada siswa ketika mengikuti pembelajaran di dalam kelas dan siswa juga terlibat aktif dalam pemeblajaran sehingga hasil pengamatan pada aktivitas siswa mengalami peningkatan dari kategori cukup menjadi baik.

\section{PENUTUP}

\section{Simpulan}

Berdasarkan deskripsi dan pembahasan hasil penelitian yang telah dipaparkan pada bab sebelumnya, maka dapat diperoleh beberapa kesimpulan sebagai berikut:

1. Aktivitas guru dalam proses pembelajaran tematik pada tema tempat tinggalku subtema bangga terhadap tempat tinggalku dengn model pembelajaran inside outside circle terjadi peningkatan. Hal ini dapat dapat dilihat dari rata-rata persentase skor aktivitas guru pada siklus I berjumlah 32 dengan persentase $64 \%$ sedangkan pada siklus II mengalami peningkatan dengan jumlah pengamatan sebanyak 44 dengan persentase $88 \%$.

2. Aktivitas siswa dalam proses pembelajaran tematik pada tema tempat tinggalku dengan model pembelajaran inside outside circleterjadi peningkatan. Hal ini dapat dilihat dari rata- rata persentase skor aktivitas siswa pada siklus I62\% dan pada siklus II sebesar $86 \%$ kategori sangat berkualitas dan telah memenuhi indikator keberhasilan.

3. Hasil belajar siswa dalam proses pembelajaran tematik pada tempat tinggalku subtema bangga terhadap daerah tempat tinggalku dengan model pembelajaran inside outside circle terjadi peningkatan. Hal ini dapat dilihat 
dari nilai rata-rata siswa pada saat prates sebelum diberikan tindakan sebesar 41,44 denan ketuntasan belajar secara klasikal 27,73\% dan dinyatakan belum tuntas. Pada siklus I nilai rata-rata meningkat menjadi 64,54 dengan tingkat ketuntasan belajar secara klasikal 54,55\%. Pada siklus II nilai ratarata juga meningkat menjadi 81,27 dengan tingkat ketuntasan secara klasikal sebesar $90,90 \%$.

\section{Saran}

Berdasarkan kesimpulan diatas, maka penulis memberikan saran yakni sebagai berikut:

1. Bagi guru

a. Seorang guru SD sebaiknya menggunkan model pemebelajaran inside outside circle dalam proses pembelajaran tempat tinggalku, khusunya pada materi tempat tinggalku.

b. Sebelum pelaksanaan membelajaran dengan model pembelajaran inside otside circle hendaknya guru mempersiapkan segala kebutuhan baik alat atau bahan yang digunakan selama proses pembelajaran sehingga pembelajaran dapat berjalan dengan baik.

2. Bagi kepala sekolah

a. Kepala sekolah hendaknya melaksanakan monitoring atau pembinaan pelaksanaan pembelajaran-pembelajaran yang inovatif seperti pembelajaran dengan model pembelajaran inside outside circle pada guru-guru SD.

b. Kepala sekolah hendaknya memberikan atau menyediakan fasilitas yang memadai kepada guru-guru SD untuk melaksanakan pemebelajaran dengan model pembelajaran inside outside circle.

3. Bagi siswa

a. Lebih aktif berinteraksi dalam kegiatan pembelajaran sehingga memiliki keterampilan-keterampilan sosial dalam bekerja sama, bertanggung jawab dan menghargai pendapat orang lain.

4. Bagi peneliti selanjutnya

a. Peneliti selanjutnya hendaknya lebih kritis dalam menghadapi masalah yang muncul dalam dunia pendidikan, khusunya dalam masalah pembelajaran 
sehingga hasil penelitian ini dapat dijadikan sebagai referensi dalam memberikan informasi tentang pelaksanaan pembelajaran.

b. Hasil penelitian ini diharapkan dapat dijadikan sebagai bahan pertimbangan bagi peneliti selanjutnya untuk menggunakanmodel pembelajaran inside outside circle dalam pembelajaran tempat tinggalku.

\section{DAFTARPUSTAKA}

Al-Tabany Badar Ibnu Trianto. 2013.Desain Pengembangan Pembelajaran Tematik. Jakarta: Prenadamedia Group

Aqibdkk, 2013. PenelitianTindakanKelas. Bandung: Yrama Widya

Carolina dkk, 2016. Penerapan Model Pembelajaran Inside Outside Circle UntukMeningkatkanKeterampilanBerbicaraBahasa Indonesia siswakelas $V$ SD Negeri 2 Banyuningtahunajaran 2015/2016 Jurnal PGSD UniversitasPendidikanGanesha. Vol.4. No 1 Pendidikan Profesi Guru, FKIP, Universitas Pendidikan Ganesha

Hamdani, 2017.StrategiBelajarMengajar. Bandung: CV PustakaSetia

Huda, Miftahul, 2013. Model-model PengajaradanPembelajaran. Yogyakarta: Pustaka Pelajar

Jihad haris ,2013. EvaluasiPembelajaran. Yogyakarta: Multi Pressindo

Komala S. Jamalullail, 2016. Penerapan Model PembelajaranInside Outside Circle untukmeningkatkanketerampilanberbicarapadamatapelajaranbahasa Indonesia siswakelas V SD Negeri 2 Banyuningtahunajaran 2015/2016

Kurniasihsani, 2016.Model Pembelajaran.AdiJay: Kata Pena

Majid, Abdul. 2014. PembelajaranTematikTerpadu. Bandung: PT Remaja Rosdakarya

Mudjiono, 2017.BelajardanPembelajaran. Jakarta: PT Rineka Cipta

Ngalimun,2016. Strategidan Model Pembelajaran.Yogyakarta: Aswaja Pressindo

NiaJulita, 2017. Pengaruh Model Pembelajaran Inside Outside Circle terhadaphasilbelajarIlmuPengetahuanAlamSiswakelas V Madrasah IbtidaiyahterpaduMuhammadiyahSukarameTahunAjaran 2017/2018. 
Noor FitriaRamadhani, 2015. Penerapanstrategi Inside Outside Circle dalamupayameningkatkanpenguasaankonsepdanhasilbelajarpadapembelajar an IPA Kelas V SDN Tlogoharum 02 wedarijaksapatiTahunajaran $2014 / 2015$.

Pulungan Intan dan Istrinani, 2017. EnsiklopediPendidikan. CV. Iscom Medan: Media Persada

Rusman, 2017. BelajardanPembelajaran. Jakarta: Kencana , 2017. Model-model Pembelajaran. Jakarta: PT Rajagrafindo Persada

Saur Tampubolon,2014. PenelitianTindakanKelas. Jakarta: PT Gelora Aksara Pratama

Shoimin Aris, 2016. Model PembelajaranInovatifdalamKurikulum 2013. Yogyakarta: AR-Ruzz Media

Siswanto Wahyudi, 2016. Model PembelajaranMenulisCerita. Bandung: PT Refika Aditama

Slameto, 2017. BelajardanFaktor-faktor yang Mempengaruhi. Jakarta: PT Rineka Cipta

Sugiyono, 2017. MetodePenelitian. Bandung: Alfabeta

Suharimi Arikunto, 2013. Dasar-dasarEvaluasiPendidikan. Jakarta: PT Bumi Aksara

Suharsimi Arikunto, 2015. PenelitianTindakanKelas. Jakarta: PT Bumi Aksara

Susanto, Ahmad, 2016. TeoriBelajardanPembelajaran di SekolahDasar.Jakarta: Prenademedia Group

Tito Hagi Darmawan, 2013. Penerapan Model Inside Outside Circle UntukMeningkatkanKeterampilanBerbicaraPada Mata PelajaranBahasa Indonesia Kelas IV SD Negeri 01 TambakboyoTahun 2012/2013

Trianto, 2009. Mendesain Model PembelajaranInovatif-Progresif. Jakarta: Prenada Media 